\title{
Legislative Note: Regulation 5(9) of the Combination Regulations under the Competition Act, 2002
}

\author{
Krishna Deo Singh Chauhan*
}

\section{Abstract}

After the provisions relating to combinations under the Competition Act, 2002 were brought into force accompanied with the coming into force of the Competition Commission of India (Procedure in regard to the transaction of business relating to combinations) Regulations, a number of uncertainties cropped up with respect to its applicability. Even after amending the regulations, in February 2012, the affected sectors still grappled with certain ambiguities in the finer details. One such issue deals with partial acquisition of an enterprise under Regulation 5(9) which has been discussed in this paper. It has been argued that no parameters have been laid down as regards the determination of the 'purpose' of the transfer of assets in cases where the transaction does not specify an express purpose. There have also been issues with regard to interpretation of these regulations in as much as even a liberal interpretation of these regulations would render the objectives of these regulations unfulfilled. Also, the dissonance between the global and Indian interpretation of these Regulations has inconvenienced the stakeholders. Taking these issues into account, it has been concluded that appropriate guidelines should be laid down to ensure that 'purpose' of the transaction can be determined with certainty and unrelated transactions are not treated as forming part of the same transaction. It has also been concluded that

*Assistant Professor (Senior Scale), College of Legal Studies, UPES, Dehradun; chuhankds@gmail.com 
following the internationally accepted position in this area of law may actually be a beneficial position to take. The paper subscribes to doctrinal research through the use of primary and secondary sources of information, which have been critically analysed.

Keywords: Combinations Regulation, Competition Commission of India, Mergers and Acquisitions, Purposive Interpretation, Regulation 5 (9).

\section{Introduction}

As a part of the process that could be described as proliferation of laws regulating market competition around the world, ${ }^{1}$ India enacted its competition law in the form of the Competition Act, 2002 (the Act). ${ }^{2}$ Subsequent to the enactment, however, it was faced with several hurdles relating to enforcement of the substantive provisions. ${ }^{3}$

The most protracted was the enforcement process of the substantive provisions relating to Combinations. ${ }^{4}$ Eventually, on 1 June 2011, Sections 5 and 6 of the Act were brought into force ${ }^{5}$ accompanied by the coming into force of the Competition Commission of India (Procedure in regard to the transaction of business relating to combinations) Regulations (the Regulations). Not only did this result in the competition law framework being

\footnotetext{
${ }^{1}$ MARK R. JOELSON, AN INTERNATIONAL ANTITRUST PRIMER 7 (Kluwer Law

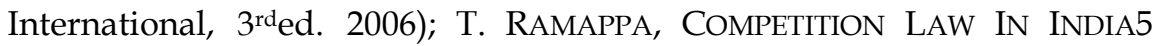
(Oxford University Press, $2^{\text {nd }}$ ed. 2011).

2 COMPETITION COMMISSION OF INDIA, available at: http:/ / www.cci.gov.in/index.php?option=com_content\&task=view\&id= 18(last visited on Sep. 22, 2015).

${ }^{3}$ BrahmDutt v. Union of India, A.I.R. 2005 S.C. 730.

${ }^{4}$ The Competition Act, $\S 5$.

${ }^{5}$ COMPETITION COMMISSION OF INDIA, Notification S.O. 479 (E) of the Competition Commission of India, available at:http://www.cci.gov.in/images/media/notifications/SO479(E),480(E),4 81(E),482(E)240611.pdf (last visited on Sep. 22, 2015).
} 
fully operational, but also established the merger control regime in India.

However, the regulations brought with them a number of uncertainties. ${ }^{6}$ Even after an attempt at resolving some of these through an amendment to the Regulations in February 2012, the affected sectors are still grappling with certain ambiguities in the finer details. The following paragraph discusses one such issue, the partial acquisition of an enterprise.

Before writing a legislative note on the chosen topic, it is worth justifying how a comment on regulations, instead of a statute is justified under this heading.

Delegated legislation has assumed a vital role in the functioning of modern democratic countries. To quote from a leading book on Administrative Law 7 :

Only a relatively small part of the total legislative output emanates directly from the legislature. The bulk of the legislation is promulgated by the executive and is known as delegated legislation... It is so extensively used today that... that the statute book will not only be incomplete but even misleading unless it be read along with the delegated legislation which amplifies and supplements it.

In this light, it is submitted that subject to various doctrinal controls over the substance and procedure of delegation, legislative powers delegated to the executive can be rightfully exercised. Further, all rules and regulations in such exercise of powers, must be considered a part of legislation and worthy of academic analysis.

${ }^{6}$ Tony Reeves \& Dan Harrison, India's New Merger Control Regime: When Do You Need to File, Antitrust, CLIFFORD CHANCE L.L.P.http://www.cliffordchance.com/content/dam/cliffordchance/PDF _2/Article_on_India_New_Merger_Control_Regime.pdf(last visited on Sep. 22, 2015).

${ }^{7}$ M. P. Jain \& S. N. Jain, Principles of Administrative LAW 269 (Lexis Nexis, $6^{\text {th }}$ ed. 2013). 


\section{Regulation 5(9) of the Combinations Regulations}

After the enforcement of the regulations in May 2011, many experts were of the view that in cases where a unit in an enterprise was being acquired, whether the applicability of the regulations for the purpose of calculation of turnover under Section 5 extended to the specific unit of the whole enterprise. ${ }^{8}$ This ambiguity also extended to the applicability of the de minimis exemption granted by the Competition Commission of India (the CCI) in March 2011. It provided that enterprises being acquired within the meaning of Section 5(a), which have assets valued at ₹ 250 crores or less or turnover of ₹ 750 crores or less, shall be exempted from the application of Section 5 (the Target Enterprise Exemption). ${ }^{9}$ Whereas it was considered prudent to take the value of the entire enterprise, it was expressed that this would undermine significantly the usefulness ${ }^{10}$ of the exemption and will also be inconsistent with internationally accepted standards. ${ }^{11}$ Subsequently, amendments to the regulations were brought into force in February 2012.12 Inter alia, the amendments inserted Regulation 5(9). It provided:

Where, in a series of steps or individual transactions that are related to each other, assets are being transferred to an enterprise for the purpose of such enterprise entering into an agreement relating to an

8 Pallavi S. Shroff, India: Merger Control, Asia-Pacific Antitrust Review 2012, GLOBAL COMPETITION REVIEW http:/ / www.globalcompetitionreview.com/reviews/42/sections/146/ch apters/1646/india-merger-control/(last visited on Sep. 22, 2015).

9 Competition Commission of India, Notification S.O. 482(E) of the Competition Commission of India, available athttp://www.cci.gov.in/images/media/notifications/SO479(E),480(E),4 81(E),482(E)240611.pdf. (last visitedon Sep. 22, 2015).

10 Reeves \& Harrison, supra note7at 97.

${ }^{11} \mathrm{Id}$.

12 COMPETITION COMMISSION OF INDIA, available at

http://www.cci.gov.in/images/media/Regulations/CCI_Combination_ Regulations_as_amended_upto_23_02_2012.pdf(last visited on Sep. 22, 2015). 


\begin{abstract}
acquisition or merger or amalgamation with another person or enterprise, for the purpose of section 5 of the Act, the value of assets and turnover of the enterprise whose assets are being transferred shall also be attributed to the value of assets and turnover of the enterprise to which the assets are being transferred.
\end{abstract}

As soon as the amendments were issued, a number of observations were made regarding the changes it brought. As regards the insertion of Regulation 5(9), it was argued that it clarifies the situation to the extent that where assets are being hived off to another enterprise, the assets and turnover for the enterprise transferring those assets will now be attributed to the transferee enterprise. ${ }^{13}$ However, it was also argued that it could lead to undesirable circumstances involving smaller transaction by large companies. 14

\title{
Analysis of Regulation 5(9)
}

As mentioned in the preceding paragraphs, it has been argued that as a result of the application of this provision, it is now clear that where assets are hived off to a new enterprise, a valuation of the assets and turnover of such an enterprise for the purposes of Section 5 of the Act will include the assets and turnover of the company which transferred the said unit. Although as a matter of practical prudence, attributing such an interpretation to this regulation may indeed be wise. However, there are two potential problems with the way the provision has been worded which suggest difficulties such interpretation:

i. No parameters have been laid down as regards the determination of what the 'purpose' of the transfer of assets is. There may be situations where such purpose is

13 Pratibha Jain, Shashank Gautam \& Simone Reis, CCI Relaxes Notification Requirements!,MONEYCONTROL.COM

http://www.moneycontrol.com/news_html_files/news_attachment/201

2/M\&A\%20Edge\%20Special_BMR\%20Advi sors.pdf(last visited on Sep. 22, 2015).

${ }^{14} \mathrm{Id}$. 
expressed. For example, in CCI v. Navyug Special Steel Private Limited ${ }^{15}$ the transfer of the steel and rings division of MUSCO to Navyug was a condition precedent to the very acquisition of Navyug by the acquirers. ${ }^{16}$ In such a situation, it might not be difficult to establish the purpose of the transaction. However, such intention of the parties might not always be documented or otherwise unequivocally expressed.

In such a situation, it might be argued that the proximity in time of the 'series of steps or individual transaction' between themselves and along with the acquisition might be indicative of the purpose. However, the potential problem with this argument is that since there is no time based consideration in the provision, as a corollary, no actual time limit has been set which will guide the CCI in inferring purpose. ${ }^{17}$ This will lead to ambiguity in the assessment of those enterprises which had transferred one of their units to a new enterprise long ago and with no specific purpose of acquisition and such enterprise would now, as per a fresh business decision wish to dispose of such subsidiary to a third party.

Thus, it is submitted that the regulation fails in drawing a distinction between two sets of transactions which are entirely different in terms of their purpose and leads to the danger of according purpose where there is none and vice versa.

${ }^{15}$ COMPETITION COMMISSION OF INDIA, Commission Registration No. C2011/12/14,

http://www.cci.gov.in/May2011/OrderOfCommission/CombinationOr ders/mitsuijan2012.pdf (last visited on Sep. 22, 2015).

${ }^{16} \mathrm{Id}$.

17 C.f., Commission Consolidated Jurisdictional Notice under Council Regulation (EC) No 139/2004 on the Control of Concentrations between Undertakings (2008/C 95/01) available at http://eur-lex.europa.eu/legalcontent/EN/TXT/?uri=CELEX:52008XC0416\%2808\%29 (last visited on Sep. 22, 2015). 
ii. The Target Enterprise Exemption provides that it exempts enterprises satisfying the conditions therein 'from the provisions of Section 5 of the said Act.' On the other hand, Regulation 5(9) provides that the attribution of the value of assets and turnover of the transferee company to that of the transferor company will happen 'for the purpose of Section 5 of the Act.'

It is submitted that where the exemption excludes the applicability of Section 5, to interpret that a valuation under Section 5 will extend to matters exempt from Section 5 might not be consistent with the literal interpretation of the provisions. Thus, literal interpretations of the two provisions taken together, suggest that the Target Enterprise Exemption will apply notwithstanding Regulation 5(9).

However, it may be argued that literal interpretation of the two provisions might not be the correct approach and under the circumstances, a purposive reading of the provisions of law may be needed. This leads us tentatively to an important question the answer which seems to have been lost sight of in the Regulation 5(9) - what is the purpose of these provisions?

\section{Purpose of the Regulatory Provisions}

For a merger control analysis under the European Union, where an acquisition 'concerns the acquisition of parts of one or more undertakings, only those parts which are the subject of the transaction shall be taken into account with regard to the seller.' ${ }^{18}$ Also, it is recognized that only those economic resources that are being subject to combination will have any impact on the market concerned and other parts of the business of the seller are irrelevant

18 Commission Consolidated Jurisdictional Notice under Council Regulation (EC) No 139/2004 on the control of concentrations between undertakings (2008/C 95/01) available at: http://eur-lex.europa.eu/legalcontent/EN/TXT/?uri=CELEX:52008XC0416\%2808\%29. 
for an analysis under the competition law. ${ }^{19}$ This recognition is consistent with the international best practices. ${ }^{20}$

However, the Indian position in this regard seems to be different. ${ }^{21}$ Although it is imperative that guidance derived from foreign legislations will be moulded according to factors relevant in Indian context, it is submitted that this particular departure from the internationally accepted standards does not appear to be satisfying any requirement unique to India. On the contrary, apprehension prevails that this requirement will continue to hamper transactions which in reality are extremely small and insignificant from a competition perspective and thus puts avoidable administrative burden on CCI as well as enterprises. ${ }^{22}$

\section{Conclusion}

The following suggestions may help to resolve the aforementioned issues:

i. As regards the valuation of the assets and turnover of the entire enterprise for the acquisition of a part of it, it is suggested that such an approach should be replaced with only such part or unit being considered.

ii. It is also noted that since the entire competition law framework in India is in a nascent stage, it is not surprising that the early stages of its implementation are rife with issues. However, it is suggested that where no patent harms are foreseen in applying an internationally accepted standard and such standard is rooted in a strong economic analysis, any alteration of such standards to suit the Indian context must be done only after careful and detailed analysis.

\footnotetext{
${ }^{19} I d$.

${ }^{20}$ Reeves \& Harrison, supra note7.

${ }^{21}$ Id.

22 Jain, Gautam \& Reis, supra note 13.
} 